\title{
'SPRECHSTUNDE': Group Research In LAw Developed Through Bilateral Student And Faculty EXCHANGE, BRAZIL-U.S.
}

\section{Catherine Tinker*}

Translating the article by Profa. Dra. Cláudia Lima Marques ${ }^{1}$ on the method of research in law that she calls 'sprechstunde" from Portuguese to English was one of my first projects upon arriving in Brazil as the CAPES Foreign Visiting Professor of Law, 2004-2005, at the Universidade Federal do Rio Grande do Sul (UFRGS) Faculty of Law, Programa de Pós-Graduação em Direito, in Porto Alegre. (See English translation of this article, supra.) In the process, I recalled how we first began to work together four years ago to create the student exchange and faculty research program funded by CAPES and FIPSE that allowed a number of Brazilian and U.S. students to study abroad for a semester and now my own selection as a Foreign Visiting Professor, "Bolsista CAPES." While reading Cláudia Lima Marques' article, I realized that, without being conscious of the method, I, too, had been trained in my masters' and doctoral studies at N.Y.U. School of Law by Prof. Thomas Franck in the same German system Cláudia Lima Marques calls "Sprechstunde" in Brazil. Cláudia and I each used this method to train the law students from UFRGS and UFPA Faculty of Law who studied with me at Pace University in New York under our CAPES-FIPSE student exchange program in 2003-2004.

* Doctorate in Law (N.Y.U. School of Law) and Master in Law (N.Y.U. School of Law); CAPES grant as Foreign Visiting Professor of Law, 2004-2005, at UFRGS Faculty of Law, Porto Alegre (Adjunta-3); Adjunct Full Professor, Pace University, New York.

1 Doctorate in Law (Heidelberg, Germany); Master in Law (Tubingen, Germany); Specialist in European Integration (Saarbrücken, Germany); Full Professor of Law, Faculty of Law of the Universidade Federal do Rio Grande do Sul (UFRGS), Department of Public Law and Philosophy of Law, Porto Alegre, Brazil; and Director, Post-Graduate Program in Law (master's and doctoral degrees in law), UFRGS, 2000-2004.

2 Cláudia Lima Marques, "Research in Law: A Testimonial on Group Research, the Methodology of 'Sprechstunde' and Learning Post-Modern Scientific Investigation, in Revista da Faculdade de Direito da Universidade Federal do Rio Grande do Sul, Vol. 20 (Porto Alegre: Nova Prova Grafica e Editora, 2001), pp. 63-89. 
The result of our group research is a book we are writing together this year in Brazil on international environmental law and comparative Brazilian-U.S. environmental law, an outline and excerpts of which are attached. The theme of our book is the importance of international environmental law and its implementation in the law and jurisprudence of Brazil and of the U.S. One purpose of the book is to make concepts and scholarly material in Portuguese accessible to readers of English. Another purpose is to identify for Brazilian readers how principles of international environmental law are part of national law, including in Brazil. These goals support the argument that international environmental law is a distinct specialty within public international law, and one to include in law school curricula.

\section{FORMING A BILATERAL CONSORTIUM FOR STUDENT EXCHANGE}

In 2000, thanks to the generous support and vision of the Tinker Foundation in awarding a two-year planning grant to Pace University School of Law to deepen the ties between our university and Brazilian institutions, I returned to Brazil ${ }^{3}$ to select projects and partners for our environmental law program, the Center for Environmental Legal Studies, at Pace University School of Law, founded by Prof. Nicholas Robinson, who had visited Brazil and worked with Antônio Benjamin through the IUCN (World Conservation Union) and academic connections. From the time of ECO-92 in Rio until 2000, Pace Law School environmental law professors ${ }^{4}$ had been invited to lecture at a series of ad hoc conferences or seminars in different parts of Brazil, ${ }^{5}$ including the states of São Paulo, Rio de Janeiro, Paraná, Bahia, Rondônia, and Maranhão. These events were variously organized by Federal courts, bar associations, or individuals (including former Pace LL.M. students from Brazil), and the panels were shared with a number of excellent Brazilian judges and law professors, such as Antônio Benjamin, Paulo Affonso Leme Machado and Vladmir de Freitas.

3 Based on my prior interest in Brazil, visits to the country over many years, some language proficiency in Portuguese, and a period of residency in Brazil some twenty years earlier under a grant in the humanities and human rights from the Rockefeller Foundation, I became the project director for the Tinker Foundation grant I helped Prof. Nicholas Robinson write for Pace Law School at the beginning of 2000.

4 Professors Nicholas Robinson, Jeffrey Miller, Ann Powers, former Dean Richard Ottinger, and others, including, more recently, Profs. David Cassuto and Lee Paddock; other professors, including myself and others from the Politics and Public Administration Department and other academic departments outside the law school, joined in presenting many seminars and lectures in English. A group of Pace law professors visited UFRGS in June, 2003, and other Pace professors have visited UFPA.

5 Similar kinds of ad hoc conferences and guest lectures were organized through the years by the Pace Business School, and other joint programs in Brazil were conducted by the Pace Nursing School; in addition, interdisciplinary service learning courses are offered to Pace undergraduate students as twoweek travel-study courses with professors from the Departments of History, Literature, or Religion and Ethics. Much of the interest in Brazil at Pace is due to the efforts over sixty years of a dedicated professor of history, now Emeritus Professor Jordan Young, who brought leading Brazilian scholars and businesspeople to Pace for guest lectures and organized exchanges of students through the business school in the past decades. Prof. Young served as a guide and advisor in our planning grant process and other activities. 
We had a sense of the growing interest in environmental law in Brazil, and wanted to establish a regular program of environmental law studies through on-going relationships with Brazilian institutions and professors who were making a similar commitment to continuity and curricular development. Another motivation was to provide an organized response to many requests for faculty to participate in conferences and from Brazilian students wanting to study at Pace, and to offer a similar option for U.S. students to study abroad. Our relationship with Prof. Antonio Benjamin and the Lawyers' Institute for a Green Planet in Brazil became the base of our future planning. At the suggestion of Prof. Antônio Benjamin, I met Profa. Dra. Cláudia Lima Marques in Porto Alegre, and we began planning a partnership for student exchange and joint faculty research that grew into a joint proposal for funding to CAPES and FIPSE.

Our first proposal was written at the very beginning of our relationship in 2000, when Claúdia and I were just getting to know each other and each other's universities, and it was driven by the deadline early in 2001 for the new FIPSE Brazil program. The critiques we received ${ }^{6}$ reflected the need to have significant ties firmly in place well in advance of the submission of the funding proposal, to find matching academic programs in both countries, or to have a track record of similar exchanges to demonstrate the means of achieving the goals of long-term cooperation. On subsequent visits to Porto Alegre in June and December, 2001, Cláudia and I fine-tuned our proposal and added another Federal university in Brazil to the consortium. I began the work of creating an administrative structure for the program in New York, with Cláudia Lima Marques doing the same in Porto Alegre, as the two founding national coordinators of our program. ${ }^{7}$ We were notified in July-August 2002 that our revised proposal was accepted by both governments, and we immediately began to operationalize the program.

Part of the preparation for this stage of the work was to meet at each university with the President and deans of the law schools and other departments to ensure the interest and commitment to the project on all sides. There were shifts in personnel involved in several of the partner universities, as the realities of negotiating the legal agreements between the universities met with the internal hierarchies of each university and the need to ensure support on the highest levels of each university. For example, there were several departments

- In an effort to reach beyond the law schools, and emphasize the undergraduate links, we initially included as a partner a private university where Pace Business School professors had offered guest lectures on business management and ecotourism, but it was not a strong match for the other partner universities.

7 In addition to Pace and UFRGS, the consortium included the University of Texas at Austin (where Prof. Benjamin organized support for our project) and the Universidade Federal do Pará (UFPA) in Belém do Pará, plus two non-governmental organizations, the Water Keepers' Alliance in New York (headed by Robert Kennedy, Jr.), and the Lawyers' Institute for a Green Planet in Brazil (headed by Eladio Lecey and Antonio Benjamin). 
or programs at UT-Austin with an interest in this program in addition to the law school, including the Lozano Long Institute of Latin American Studies (LLILAS) headed by Prof. Nicholas Shumway, and the Environmental Sciences Institute in the Department of Geography, an interdisciplinary team of environmental scientists. At Pace, the decision was made to make the program university-wide, rather than a program of the law school alone, and a newly-hired assistant provost, Dr. Beverly Kahn, became the head of the program in 2002, ensuring its sustainability within Pace University by putting the Brazil exchange program high on Dr. Kahn's agenda for internationalizing the university and its programs. Dr. Nicholas Shumway became the coordinator of the program at UT-Austin, in cooperation with Prof. Patricia Hansen of the UT-Austin School of Law and ESI.

Following the CAPES-FIPSE meeting of the consortia in October, 2002, in Brasilia, I returned to Belém do Pará and to Porto Alegre with a representative of the University of Texas at Austin, to meet again with the responsible parties at UFPA and UFRGS and to continue to work on the draft cooperation agreement. We concluded our legal agreements in record time (signed copies were ready by the following February or March with all the universities), aided by two important factors: the model agreement we used was an existing academic cooperation agreement for student and faculty exchange between the University of Texas at Austin School of Law and the UFRGS Faculty of Law; and by the time we negotiated the agreements, our relationships were firm and cemented by mutual visits. It may have helped that three universities in our consortium had lawyers as program coordinators (Cláudia Lima Marques for UFRGS, Jorge Alex Nunes Athias and Christina Oliveira Dourado for UFPA, and myself for Pace).

Once the legal cooperation agreements were signed by the President or legal authority of each partner university, including the tuition waiver and acceptance of transfer credits requirements, we were ready to submit our first-year report to FIPSE and CAPES in order to receive the funds for the first group of exchange students. The first UFRGS law students under our exchange program arrived in Austin in January, 2003, for a semester. ${ }^{8}$ The first UFRGS and UFPA law students arrived in New York in July, 2003, to study for a semester at Pace University. ${ }^{9}$ The U.S. students arrived in Brazil beginning in August, $2003 .{ }^{10}$ To date, nine Brazilian law students from UFRGS and UFPA have studied at Pace University in New

8 Antonia Klee, Lucas Faria Annes, and Melissa Castello were the first group; Ana Gerdau de Borja, Tâmara Joana Biolo Soares and Mariana Pargendler artived in January, 2004, for a semester. A UFRGS student from the interdisciplinary TERMISUL project (environmental law encyclopedia and multjlingual glossary of international environmental law terms) also studied at UT-Austin, and several other UFRGS law students studied at UT-Austin Law School outside the FIPSE-CAPES program.

9 Maite de Souza Schmitz, Thomaz Silveira de Araujo Santos and Rafael Pelligrini Ribeiro. In January, 2004, Miguel Kreling and Laura Miller arrived in New York for their semester study.

${ }^{10}$ UT-Austin law student Jay Bischoff arrived at UFRGS in January, 2003; Cory Hash and Seth Otto arrived in Porto Alegre in August, 2003 to study at UFRGS; and Shaun Schottmiller arrived at UFRGS in August, 2004. Pace student Ana dos Santos arrived in Belém do Pará to study at UFPA in August, 2003. 
York and another eleven students have studied at UT-Austin School of Law during 20032004, the first year and a half of the CAPES-FIPSE grant. Three UT-Austin law students and two others have studied at UFRGS Faculdade de Direito, and one Pace student has studied at UFPA.

On my next trip to Brazil, I was invited to give another guest lecture at UFRGS Faculty of Law for the Programa de Pós-Graduação em Direito, a feature of every visit I made to Brazil during our planning period from 2000 on, and participated in interviews of UFRGS law students applying for the exchange program in the United States. On several visits to Belém do Pará setting up the exchange program there, I was also invited to give guest lectures at the law school at UFPA, and I met the Brazilian law students who had been selected to study in the U.S. under our exchange program. These contacts created connections between the institutions and individual students and faculty that contributed to the success of the student exchanges. Similarily, we made an effort to recruit students to study in Brazil, and the coordinator in Belém, Jorge Alex Nunes Athias, interviewed possible candidates on one of his trips to New York. Profa. Cláudia and Antônio Benjamin did the same in Austin, Texas, at a conference held during the annual semester-long course Prof. Benjamin teaches at UT-Austin School of Law, and on other visits to UT-Austin.

When Cláudia Lima Marques visited Pace University in New York for the first time in 2003, she gave a guest lecture in my class on "Sustainable Development Law and Policy," an interdisciplinary seminar with law students and students from the Politics and Public Administration Department, and met some possible candidates for exchange study. Since then, Prof. Benjamin spoke at Pace as a keynote speaker at a conference in June, 2004, organized and funded by the Tinker Foundation to build on the FIPSE-CAPES grant for the basic student exchange. ${ }^{11}$ Other visits by UFRGS and UFPA law professors to UTAustin occur on a regular basis for guest lectures or periods of library research; one such scholarly exchange, during which Professor Cesar Saldanha Souza of UFRGS Faculty of Law spent several months researching in Austin and writing a book. Faculty from the Departments of Politics, Business, History, Religion and Ethics, and Literature and Languages from Pace University have traveled to Brazil with funding independent of the CAPES-FIPSE grant, and short-term travel-study programs have brought small groups of Pace students to Brazil for a week or two from various departments. UT-Austin law school and LLILAS faculty regularly travel to Porto Alegre every August for conferences and joint research under other programs, and more UT-Austin faculty will return in January, 2005. UT-Austin and Pace professors are also invited to lecture at UFPA when they are in Brazil. With my arrival in Porto Alegre, his year marks the first time that a Foreign Visiting Professor from the U.S. funded by CAPES is teaching at the UFRGS Faculty of Law, although several German professors co-funded by their government have taught at UFRGS law school in the past.

1 This subsequent Tinker Foundation grant, which I also wrote for and with Pace University, will result in a joint conference in Brazil in 2005. 


\section{LEARNING TO RESEARCH IN INTERNATIONAL LAW: A PERSONAL ACCOUNT IN RESPONSE TO CLÁUDIA LIMA MARQUES' TESTIMONIAL ON HER METHOD OF RESEARCH IN LAW}

My initial international experience was to participate in two Model United Nations sessions as a high school student; and then as an exchange student during my university years: one semester at Chulalongkorn University, Bangkok, Thailand, and one semester in Aix-en-Provence, France. During law school at George Washington University, I served as one of the student editors of the international law journal prior to receiving the J.D. degree. After graduation, and some experience as a prosecutor, I became a law clerk to the Chief Judge of the United States District Court for the Southern District of New York in Manhattan, Ch. Judge Charles L. Brieant. The duties of a Federal law clerk are to research cases and analyze briefs for the judge in cases where, depending on the judge, the clerk may prepare a rough draft of the opinion for the judge, outlining the facts, the legal reasoning, and the arguments the judge may use to decide the case. I learned the rigor required for this type of legal research, the need to carefully analyze the legal arguments put forth by the lawyers for both sides in the litigation, and the high level of scrutiny with which each argument must be weighed in order to reach a fair, equitable, and legally correct judgment likely to be upheld in case of an appeal.

I also observed the seriousness with which every case was handled by my judge, especially in cases where the claimant had no lawyer and was representing himself (pro se cases). From this position, which is usually a year or two, I decided I really wanted to teach international law, and wanted to earn a master's degree.

New York University School of Law's Center for International Legal Studies, founded by Professor Thomas Franck, selected me as the Senior Fellow for two years during my studies for the master's (LL.M.) and doctor of juridical science (J.S.D.) degrees in international law. There I learned how to research as a research assistant to several professors during my year's study for the LL.M., first with Professor Theodore Meron (now Chief Judge of the Ad Hoc Tribunal on the Former Yugoslavia) on a history of humanitarian law in which I read the records of the founding of the United Nations, including the U.N.C.I.O. in San Francisco. Then I became a research assistant to Professor Thomas Franck, who later agreed to become my dissertation advisor when I became a doctoral candidate.

Professor Franck chose junior and senior fellows to become part of his Center for International Legal Studies for a year, with a weekly seminar meeting as the focus of our studies on a theme of international law selected by Professor Franck each year. Within the broad theme, each student fellow selected a specific topic to research with the approval of Professor Franck. Research included library research in the excellent N.Y.U. Law School Library, and in my case, the Dag Hammarskjold Library at the United Nations. When indicated, Professor Franck provided introductions to practitioners of public international law, such as Secretariat officials and diplomats at the United Nations, for interviews. Another formative experience for all of us fellows was Professor Franck's invitations to dinners at N.Y.U. Law 
School with noted international scholars from, for example, during my time, Finland, South Africa, and Japan. We were exposed to new currents of thought, proponents of different schools of jurisprudential analysis, and the most creative thinkers in the field of international law who would make a presentation based on their current research, followed by questions from the guests, including respected international lawyers representing their countries at the United Nations. Informal conversations occurred over the dinner table, where Professor Franck carefully introduced each fellow to the other guests.

The final event of each year marked the completion of the research papers with an evening of presentations by fellows, followed by critiques from the dinner guests, who had read the papers in advance and were ready to engage in dialogue with the fellows. This was an amazing lesson in combining theory and practice, sharing insights into public international law from the perspective of the academy and the real world of diplomacy and international policy-and law-making. We as fellows were welcomed as part of the group looking for ways to implement the ideas of the United Nations Charter and achieve the goals articulated by the international community, and we observed the way that serious scholars and diplomatscholars interacted in seeking solutions to global problems, while hearing the stories behind the stories and the meaning of certain language in negotiated documents of international law. Finally, selected fellows' papers were published by the N.Y.U. Law School Journal of International Law and Policy, including my article on the environment and the United Nations. ${ }^{12}$

My dissertation committee was headed by Professor Franck, with Professor Andreas Lowenfeld (expert on private international law and arbitration), and Professor Paul Szasz (instrumental as a lawyer for the United Nations role in the independence of Namibia and in the creation of the ad hoc commission for the former Yugoslavia). The year that I was formulating my dissertation proposal, Professor Franck was at the Max Planck Institute, working on the manuscript for his book on democratic elections and the role of the individual in public international law. The seminar course he normally offered for post-graduate students was offered by Professor Oscar Schachter of Columbia University School of Law, following his career in the Legal Advisor's Office of the United Nations, who that year was involved in the foundations of the field of international environmental law in the years leading up to the United Nations Conference on Environment and Development, held in Rio de Janeiro in 1992. Under his influence, I became involved as a NGO representative at the Preparatory Committee meetings for the Rio Conference, the Rio Conference itself and the final negotiating sessions of the United Nations Convention on Biological Diversity. These experiences inspired my research and writing for Professor Franck, and resulted in the publication of several chapters in books and law review articles on international law and

12 "Environmental Planet Management by the United Nations: An Idea Whose Time Has Not Yet Corne?"

22 N.Y.U. Journal of International Law and Politics 793 (Summer 1990) 
biological diversity ${ }^{13}$ as well as subsequent work for non-governmental organizations at the United Nations. ${ }^{14}$

In the course of my dissertation work, with Professor Franck's recommendation, I was hired by the Ford Foundation for a summer to research archival materials from the beginning of the United Nations related to the role of the Secretary-General for former Under-Secretary-General Brian Urquhart. ${ }^{15}$ In the course of the research in the U.N. archives and the national archives of several key states from 1945-1946, we confirmed that no rule was ever adopted regarding the length or renewability of the term of office of the SecretaryGeneral, only customs. Two years later, I was still working with Sir Brian on this study of the role and selection of the Secretary-General with recommendations, including one for a single seven-year term. In the course of preparing the manuscript, several advisory group meetings were convened in which I observed how actual participants in the historical events we analyzed, including former foreign ministers and diplomats from all over the world, responded to the issues and recalled the reasons for certain developments in the political history of the United Nations.

Following the publication by the Ford Foundation and the Dag Hammarskjold Foundation of our study on the U.N. Secretary-General, I accepted a year's appointment as the senior policy analyst for the United Nations Association - USA branch, the organization that sponsors the Model United Nations programs worldwide. My research training and familiarity with the leading scholarly work in international law helped me prepare a research agenda and sponsor a series of off-the-record discussions with key Secretariat officials, selected

13 "Responsibility for Biological Diversity Conservation under International Law," in INTERNATIONAL LAW: AN ANTHOLOGY, ed. Charlotte Ku and Paul F. Diehl (Boulder, Colorado:Lynne Reiner, 1998), pp. 415-442; "State Responsibility and the Precautionary Principle," in THE PRECAUTIONARY PRINCIPLE AND CHANGES IN INTERNATIONAL ENVIRONMENTAL LAW AND POLICY, ed. David Freestone and Ellen Hey (Dordrecht, Holland: Kluwer, 1996), pp. 53-71; "UN Convention on Biological Diversity, One Year After Entry into Force,"-28 Vanderbilt Journal of Transnational Law 777 (October 1995); "A New Breed' of Treaty: The UN Convention on Biological Diversity," 13 Pace Environmental Law Review 191 (Fall 1995); "Introduction to Biological Diversity: Law, Policy, and Science," 1 Buffalo Journal of International Law 1 (Spring 1994); "Environmental Security in the United Nations: Not a Matter for the Security Council," 59 Tennessee Law Review 787 (Summer 1992); "Strict Liability of States for Environmental Harm," 3 Touro Journal of Transnational Law 155 (1992).

${ }^{14}$ See, e.g., an account of this NGO experience in "Parallel Centers of Power: The View of NonGovernmental Organizations at the United Nations," in CONSCIOUS ACTS AND THE POLITICS OF SOCIAL CHANGE: FEMINIST APPROACHES TO SOCIAL MOVEMENTS, COMMUNITY, AND POWER, ed. Robin L. Teske and Mary Ann Tetreault, University of South Carolina Press, 2000, pp. 219-229.

15 Sir Brian is a retired career civil servant in the United Nations Secretariat who had served with every Secretary-General since the beginning of the organization, and who is the author of noted biographies of Dag Hammarskjold and Ralph Bunche. He is often interviewed as an expert on international relations and the United Nations. 
NGO representatives and diplomats on cutting edge issues and policy decisions at the United Nations involving international law. By this time, I incorporated a non-profit organization for education and research on international law and organizations, TIILO, ${ }^{16}$ the organization I represented then at the Rio conference and many subsequent United Nations meetings on topics related to international environmental law.

From all these experiences, I then began teaching international law, the goal I had formed when I decided to return to law school for the LL.M. The policy work and the experiences at the United Nations contributed to my scholarship and teaching. It also continued to draw me back to research projects with the approach of solid research and analysis as the base for publications that reach a wide policy audience. Such was the opportunity I had to direct the project that resulted in the publication entitled Crossing the Divide: Dialogue among Civilizations (New Jersey: Seton Hall University, 2001). A collaborative effort of a Group of Eminent Persons, principally former Under-Secretary-General of the United Nations Giandomenico Picco, we declared our commitment to the value of diversity and respect for difference as a rejection of the thesis of the clash of civilizations propounded by Samuel Huntington. Published by a university, this report was presented to SecretaryGeneral Kofi Annan, who distributed it to each member state of the United Nations before the General Assembly debate on the subject of Dialogue among Civilizations.

Another example of "sprechstunde" at N.Y.U. School of Law, noted for its international law scholars, was the tribute given to Prof. Franck upon his retirement from full-time teaching at N.Y.U. All former Fellows of the Center for International Legal Studies were invited back to the Law School to honor Prof. Franck over a two-day period which included, of course, several dinners and testimonials. Significantly, the event was designed as a min-conference of leading international law scholars and practitioners, all trained by or influenced by Prof. Franck, presenting their current research or thought-provoking questions for group discussion during the testimonial, followed by publication of the papers in the N.Y.U. Journal of International Law and Politics. ${ }^{17}$

In short, developing research skills in groups and under the direction of my masters of international law, chiefly Professor Thomas Franck and Professor Oscar Schachter, has been a solid foundation for many professional activities, including teaching, research and writing, and policy work. Some of the lessons I learned are those I share with my students

${ }^{16}$ The Tinker Institute on International Law and Organizations (TIILO) is accredited to the United Nations through ECOSOC with roster status. We are a voluntary non-profit organization interested in international legal aspects of biological diversity, sustainable development and gender equity. See www.tiilo.org.

17 "Conference: International Law and Justice in the Twenty-First Century: The Enduring Contributions of Thomas M. Franck," N.Y.U. Journal of International Law and Politics, vol. 35, Winter 2003, No. 2, pp. 291-517. The articles are by Benedict Kingsbury, Harold Hongju Koh, Philip Allott, Nathaniel Berman, David Golove, David Kennedy, Karen Knop, Martti Koskenniemi, and David M. Malone. 
each year, encouraging them to dedicate themselves to serious research and participation in policy-and law-making in the international context. By preparing themselves through this process, they will know enough history to handle the many changes and challenges ahead in their professional lives, and find creative solutions to the events of their era. By reading the works of masters like Prof. Franck, we can all share in his vision of "legal cosmopolitanism" and fulfill our potential as members of the "invisible college of international law." Surely Thomas Franck's legal scholarship exemplifies the best of the hermeneutic method of legal scholarship, known for its intellectual rigor and its insight and vision, as well as for the beauty of his use of languages. This is a model for our students in the future.

\section{CREATING A BILATERAL GROUP FOR RESEARCH IN LAW}

An important dimension to this preparation is the experience of living in another culture for long enough to understand something of the similarities of humankind and the special differences of various cultures and languages. This is why student exchange programs are so important, especially semester-long experiences where the students learn and use another language. From the first meetings of the parties to our consortium with the University of Texas-Austin, UFRGS, UFPA, and Pace University, we discussed the kind of joint research and collaborative efforts of faculty that could accompany student exchange and lead to longterm relationships on an institutional and personal level. Our collaborative effort to design a partnership and elaborate an exchange program with a language requirement anticipated comparative legal studies and research opportunities for the students under the direction of professors. We also hoped for faculty visits and joint research projects to evolve from the exchanges.

Just as students learn how to research from experiences with professors, so also we as professors learn to expand our thinking and add new areas to our research agendas. In beginning to research in another legal system, and in another language, it is critical for professors to have time to live in that other culture and combine the research with teaching. Working with students from another legal system offers richly rewarding opportunities to learn from one another, even in formulating questions and sharing reactions to assigned reading and suggested bibliographic entries. Another benefit of this experience is to gain insights into one's own legal system by exploring the bases for another legal system. In the process of finding the correlation for legal terms by researching in another language, the student or professor also learns another language on a level of professional communication, achieving the ability to write reports, formulate bibliographies, and explain theoretical or abstract ideas with support for the positions or arguments advanced. Real facility in these activities develops through joint research and exchange of ideas with daily interactions in the classroom and meetings of research groups.

The first groups of Brazilian law students to study at Pace University in New York in 2003-2004 included four students from UFPA Faculty of Law and five students from UFRGS Faculty of Law. They successfully completed their courses, received high grades 
from the law school professors, and completed research papers while they were in New York. Since all the students who came to New York had indicated interest in environmental law, they all participated in my seminar on Sustainable Development Law and Policy, an interdisciplinary seminar on law and politics. We continued to meet as a group to discuss future research together on comparative U.S.-Brazil environmental law, and contributions to a book. Several meetings took place in November and December, 2003, in New York, emails were exchanged in February and April, and we met again in Brazil in August and September, 2004, when my own exchange visit began at UFRGS Faculty of Law courtesy of a CAPES Foreign Visiting Professor appointment.

As a result of our group effort we plan to publish a book, an example of the academic substance achieved through the exchange program funded by FIPSE and CAPES. Included in the book will be papers by most or all of the Brazilian law students in New York in 2003-2004, along with the translation of the Sprechstunde article by Cláudia Lima Marques and my introduction to the subject of international environmental law as a distinct field of study within public international law. (outline attached) $)^{18}$

An important part of the book is a bibliography compiled jointly by the entire group, which will be annotated in English to make the works of leading Brazilian scholars in international law and environmental law accessible to English-language readers. One of the reasons for the lack of knowledge about Brazilian environmental law in North America and elsewhere is the difficulty of researching Brazilian legal materials, and knowing what is

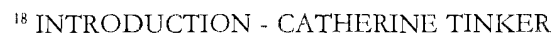

THE DEVELOPMENT OF THE FIELD OF INTERNATIONAL ENVIRONMENTAL LAW; OVERVIEW OF INTERNATIONAL ENVIRONMENTAL LAW- PRINCIPLES, PROCESSES AND INSTITUTIONS; AND NATIONAL IMPLEMENTATION IN THE US. AND BRASIL

1. SOURCES OF INTERNATIONAL ENVIRONMENTAL LAW

2. PRINCIPLES OF INTERNATIONAL ENVIRONMENTAL LAW

3. USE OF PRINCIPLES OF INTERNATIONAL ENVIRONMENTAL LAW

A. IN MULTILATERAL ENVIRONMENTAL TREATIES

B. IN JURISPRUDENCE IN INTERNATIONAL TRIBUNALS

C. IN INTERNATIONAL INSTITUTIONS

4. COMPARATIVE U.S.-BRASILIAN ENVIRONMENTAL LAW

A. METHODOLOGY

B. CONSIDERATIONS

1. SUBSTANTIVE

2. PROCEDURAL

3. INSTITUTIONAL

C. RESULTS

5. EXAMPLES OF THE USE OF THE PRINCIPLES OF INTERNATIONAL ENVIRONMENTAL LAW IN NATIONAL LEGISLATION AND JURISPRUDENCE

A. U.S. (CASE STUDIES)

B. BRASIL (CASE STUDIES)

CHAPTER I AND STUDENT CHAPTERS: SEE ATTACHED COMPLETE OUTLINE OF BOOK ANNOTAT'ED BIBLIOGRAPHY 
the most reliable among a multitude of sources. By providing a basic annotated bibliography as a result of our joint research, we will provide a resource to other researchers that may stimulate further exchanges and collaborative works in the future.

This volume will serve as an inspiration to others who might participate in future exchanges, and encourage this special group of students to continue their professional developrnent as researchers, lawyers and future professors. It is also a testament to the way, under the tutelage of Cláudia Lima Marques and her colleagues in Brazil and with my assistance in New York, this group of students helped one another adjust to the challenges of living and working in a very difficult and different atmosphere, language and culture, and succeeded both individually and collectively. Their interest in continuing to work with me in researching and preparing a manuscript indicates how close the ties become when group research is undertaken, and how the shared insights across cultures deepen understanding and indicate areas for future research together. In the process of learning together, my students have taught me much about Brazilian law and culture, and been patient with me while I am teaching my law school classes in Portuguese. We have together seen how important it is to understand another culture through language study and experience living in another country as a basis for comparative studies, and we have come to appreciate how this type of deep learning takes time. With the luxury of a semester or more abroad, we have all come to see much more about each other's culture and legal system, and to appreciate our own.

Thank you to all who contributed to this project in its many phases, and especially to my partner in international law, whether public or private, Profa. Dra. Cláudia Lima Marques, and to my inspiration and guides, Prof. Antonio Benjamin, Prof. Nicholas Robinson, Prof. Thomas Franck, and the late Prof. Oscar Schachter. Thank you to CAPES for the great honor and generous support for my teaching and research at UFRGS Faculty of Law as the Foreign Visiting Professor for 2004-2005. And thank you to all the students in the CAPES-FIPSE exchange program, who are the future. 